\title{
A Study of Trade Efficiency and Potentials between Jiangsu Province and the Countries along the Belt and Road Initiative
}

\author{
Jiayu Wang*, Wen Tian \\ Nanjing Normal University (NNU), Nanjing, China \\ Email: *wangjiayuxf@126.com
}

How to cite this paper: Wang, J. Y., \& Tian, W. (2020). A Study of Trade Efficiency and Potentials between Jiangsu Province and the Countries along the Belt and Road Initiative. Open Journal of Social Sciences, 8, 143-157.

https://doi.org/0.4236/jss.2020.82013

Received: January 19, 2020

Accepted: February 23, 2020

Published: February 26, 2020

Copyright ( 2020 by author(s) and Scientific Research Publishing Inc. This work is licensed under the Creative Commons Attribution International License (CC BY 4.0).

http://creativecommons.org/licenses/by/4.0/

\section{(c) (i) Open Access}

\begin{abstract}
This paper applies Stochastic Frontier Analysis (SFA) to a broad data set for selected 48 countries along the Belt and Road from 2002 to 2017, and analyzes foreign trade potential and trade efficiency between Jiangsu Province and countries along the Belt and Road. The empirical analysis shows that trade efficiency of Jiangsu Province has been improved gradually year by year in general. From the view of natural factors, the research identifies market size, establishment of diplomatic relation and the bilateral geographical distance between Jiangsu Province and countries can stimulate Jiangsu Province's foreign trade respectively. From the perspective of human factors, one-step model discovers that government efficiency, political stability and investment freedom are crucial to improving trade efficiency. However, financial freedom and the current situation of transportation infrastructures will aggregate inefficiencies to some extent. Based on these findings, the paper proposes how to expand foreign trade and improve trade efficiency between Jiangsu Province relative to countries the Belt and Road Initiative.
\end{abstract}

\section{Keywords}

Trade Potential, Trade Efficiency, Stochastic Frontier Gravity Model, The Belt And Road Initiative

\section{Introduction}

Jiangsu Province boasted an outstanding performance in 2017 and has successfully become the second province after Guangdong province to surpass 4 trillion yuan in total imports and exports. As a crucial intersection in terms of the Belt and Road Initiative, Jiangsu Province has actively invested in the Belt and Road 
construction and comprehensively deepened economic and trade cooperation with these countries with exports increasing from $\$ 5.574$ billion in 2002 to $\$ 87.191$ billion in 2017, at an average annual growth rate of $91.52 \%$, accounting for the total exports of Jiangsu Province in the same period from $11.03 \%$ to $24.01 \%$. It can be seen that, thanks to the strategy of the Belt and Road, the total value and share of Jiangsu Province's exports to those countries have both increased dramatically. However, the vast majority of trading partners along the Belt and Road are developing countries or emerging economies with different national conditions and backgrounds. Additionally, China's economy is under new downward pressure. Against all these factors, it is worth to explore whether Jiangsu Province can maintain and improve its exports to the Belt and Road countries. As an important indicator to measure performance of a country's foreign trade, trade efficiency and potentials are crucial to exploring the dynamics and development trends of Jiangsu Province.

Since the launch of the Belt and Road Initiative in 2013, academic researchers conduct a series of qualitative and quantitative analysis mainly on the background and significance of this proposal, strategic ideas and trading strategies, trade structure and competitiveness of partner economies along the route (e.g. Lin, 2017; Hu, Ma, \& Yan, 2014; Sheng \& Li, 2016; Pei et al., 2015). With continuous deepening of research in these fields, issues of trade potentials and trade efficiency attract more and more attention. Early gravity model is widely used to probe trade efficiency and potentials due to its simplicities (e.g. Sheng \& Miao, 2004; Tang, Shao, Li, \& Wang, 2018; Chen \& Chen, 2018; Kong \& Dong, 2015). However, such a conventional framework usually classifies unpredictable resistance factors into disturbance residual terms, which leads to biased estimation (Battese \& Coelli, 1992). Nowadays, stochastic frontier model comes to the spotlight and becomes the mainstream model since it owns two error terms, one to account for trade efficiency and the other to explain other factors in trade variables.

Literature using stochastic frontier models can be broadly divided into two categories. On one hand, scholars conduct quantitative analysis using time-invariant and time-varying stochastic frontier models from perspective of national perspective, and find that exports efficiency between China and countries along the line increases with time, and trade potential is growing (e.g. Zhang \& Yin, 2018; Sun \& Liu, 2016). There also exist some scholars who focus on bilateral trade or trade among some certain countries or regions (e.g. Liu et al., 2018; Huang \& Gong, 2014; Tan \& Zhou, 2015; Chen \& Li, 2019; Hou \& Deng, 2017). On the other hand, scholars estimate exports potentials of specific industries based on industry perspectives (e.g. Li \& Lyu, 2019; Deng et al., 2019; Chang, Wang, \& Han, 2018; Zhang \& Zeng, 2017).

All in all, scholars conduct both theoretical and empirical researches and study trade development between China and countries along the Belt and Road from different perspectives. The data are basically based on the national level, and less research is done on the provincial level. As a major trade and manufacturing 
base, trade development between Jiangsu Province and its exports with the Belt and Road countries matter a lot when it comes to national development strategies. Jiangsu Province is expected to explore how to accelerate bilateral trade and investment among countries. So, it is crucial to studying trade efficiency and potentials between Jiangsu Province and countries along the Belt and Road.

In this paper, we conduct frontier analysis to explore trade efficiency and trade potentials and their determinants based on the stochastic frontier time-varying model. The factors affecting trade efficiency are economic scale, population size, trade distance, and border. We also include government efficiency, political stability, investment freedom, financial freedom, communication infrastructure and Transportation infrastructure level to explain trade non-efficiency. Particularly, we take the duration of the establishment of diplomatic relations into account. Based on the availability of data, 48 countries along the route are selected to form the panel data from 2002 to 2017 for empirical testing.

\section{Current Situation of Trade Cooperation between Jiangsu Province and the Belt and Road Countries}

\subsection{The Overall Trade Scale between Jiangsu Province and the Belt and Road Countries}

In recent years, Jiangsu's foreign trade has developed rapidly. The total import and export volume of Jiangsu Province in 2002 reached $\$ 70.305$ billion, of which exports were $\$ 38.480$ billion. Imports and exports have increased to 591.139 billion, of which exports accounted for $\$ 363.298$ billion, and the average annual growth rate of exports was $14.11 \%$ in 2017 . At the same time, Jiangsu Province exports to the countries along the Belt and Road grew dramatically. In 2017, Jiangsu's exports to these countries reached about $\$ 878.20$ billion, up from $\$ 767.52$ billion in 2016, with an annual increase rate of $16.3 \%$.

During the sample period, the total imports and exports, imports and exports of Jiangsu Province to countries along the Belt and Road shows a rising trend with greater proportion of exports (see Figure 1). From the perspective of imports, from 2002 to 2008, Jiangsu's imports from selected countries along the route increased from $\$ 5.927$ billion to $\$ 41.416$ billion, with an average annual growth rate of $30.01 \%$, showing a steady growth trend. Affected by the financial crisis in 2008, the figure plummeted to $\$ 31.230$ billion. Since the global economy has gradually recovered, imports have increased ups and down, reaching \$52.849 billion in 2017, an increase of 7.92 times over that in 2002. As for exports, from 2002 to 2017, although with some fluctuations due to financial crisis, the number generally showed an upward trend. In 2002, Jiangsu's exports to countries along the route amounted to $\$ 5.574$ billion, and in 2017 it reached $\$ 87.191$ billion. Influenced by 2008-2009 financial crisis, the growth rates of imports and exports dropped respectively, then increased sharply after 2010. The growth rates of three trade curves continued to increase in 2015. Although with some fluctuations, it can be seen that Jiangsu's exports grew at a slower rate than imports. 


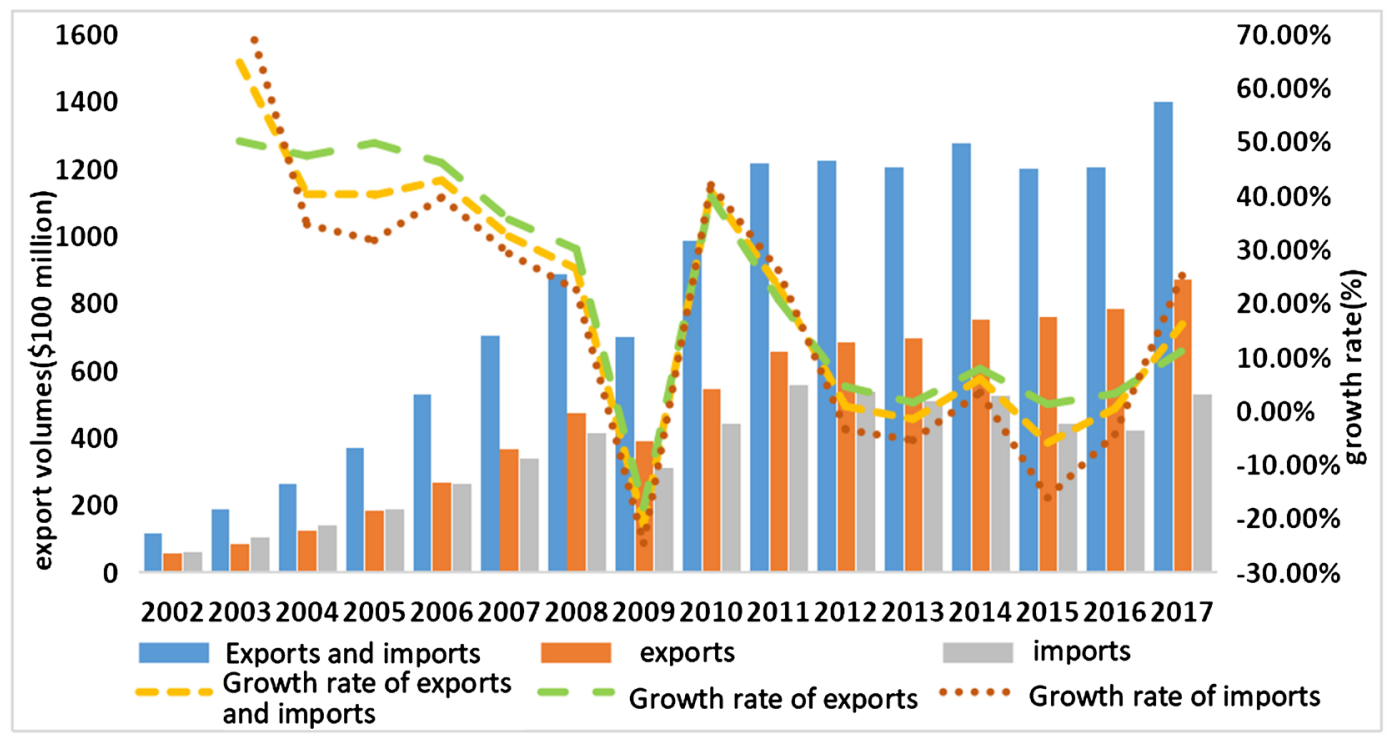

Figure 1. Trade between Jiangsu Province and countries along the Belt and Road, 2002-2017.

\subsection{Spatial Distribution of Trade between Jiangsu Province and Countries along the Belt and Road}

Due to geographical locations, climate, resources endowment and other factors, trade performance between Jiangsu Province and countries along the Belt and Road represents various characteristics. Based on the study of Jiangsu Province and 48 countries along the line, growth in exports between Jiangsu Province and countries along different regions in 2002-2017 increased ups and down. Due to global financial crisis in 2008, Jiangsu Province exports to East and South Asia, Central and Eastern Europe, Western Asia, and the CIS shrank more or less, but the number rebounced in 2009, after that the growth rate was stable. When it comes to different regions, in 2002, Jiangsu exports to Mongolia and Southeast Asia accounted for the largest share (55.74\%) of total exports, reaching about $\$ 3.107$ billion. Western Asia and South Asia followed, with $\$ 925$ million and $\$ 840$ million. Besides, Jiangsu Province exported about $\$ 290$ million in goods to 7 countries of the CIS. Exports to Mongolia and Southeast Asia in 2017 accounted for 47.98 percent of Jiangsu Province's total exports, compared to 21.14\% from South Asia, 14.07\% from West Asia, 10.47\% form Central and Eastern Europe, and 6.33\% from CIS. In general, Jiangsu Province exports to countries along the route continued to increase during the sample period with growth rate varying by regions. Jiangsu Province has established the closest trade connections with 9 countries in East and Southeast Asia and 13 countries in West Asia, while trade connections with the CIS are relatively low.

\section{Model Settings and Data Sources}

\subsection{Model Settings}

Firstly, this article uses a stochastic frontier gravity model to estimate trade potentials and efficiency based on previous papers. The model is specifically set as 
follows:

$$
\begin{aligned}
\ln E X_{i j t}= & \beta_{0}+\beta_{1} \ln \left(P G D P D_{i j t} * P G D P F_{i j t}\right)+\beta 2 \ln \left(P O P D_{i j t} * P O P F_{i j t}\right) \\
& +\beta_{3} \ln D I S_{i j}+\beta_{4} \ln \text { Border }_{i j}+\beta_{5} \ln R E L A T I O N_{i j}+v_{i j t}-u_{i j t}
\end{aligned}
$$

where $i$ represents Jiangsu Province; $j$ represents trade partners; $E X_{i j t}$ is exports from $i$ to country $j$ in year $t$. The core explanatory variables are the following four groups: 1) $P G D P F_{i j t}$ and $P G D P D_{i j t}$ are the per capita GDP of exporting and importing countries, which represent the level of economic development and consumption. The higher the economic level, the stronger the production capacity or purchasing power, the ability to use its comparative advantages to provide more products or create a huge consumer market, the impact is expected to be positive; 2) $P O P D_{i j t}$ and $P O P F_{i j t}$ represent the total population of Jiangsu Province and country $j$. They represent market size, which can drive domestic demand. 3) $D I S_{i j}$ is the transportation distance between $i$ and country $j$, which reflects the cost of trade. The impact on trade volume is expected to be negative; 4) BORDER $R_{i j t}$ is a dummy variable for adjacent countries, and the expected impact is positive. Considering few documents cover the impact mechanism of the duration of diplomatic relations, we take this indicator into account, RELATION $i j$ indicates the length of time for the establishment of diplomatic relations between countries, the expected sign is positive.

What are the factors determining trade efficiency? To further analyze factors of influencing trade inefficiency, scholars generally adopt a two-step method or a one-step method. Considering inconsistencies in the assumptions of the two-step model, we adopt the one-step method and incorporate exogenous factors such as government effectiveness and investment freedom into inefficiency terms as follows:

$$
u_{i j t}=\partial_{0}+\partial_{1} \ln F I X_{j t}+\partial_{2} \ln A K_{j t}+\partial_{3} I N F_{j t}+\partial_{4} F F_{j t}+\partial_{5} E F F I_{j t}+\partial_{6} P S_{j t}
$$

1) infrastructure: $F I X_{j t}$ is the number of fixed telephone users per 100 people and $A K_{j t}$ is the number of air transport passengers, both of which reflect national level of infrastructure such as communications and transportation, and the expected coefficients are negative; 2) institutional environment: $E F F I_{j t}$ indicates government efficiency of a country. It reflects the quality of a country's policy formulation and implementation. $P S_{j t}$ indicates political stability. It is generally believed that the more stable national political situation, the higher the government efficiency and the more conducive to trade development. Expected coefficients are all negative; 3) Economic system environment: $I N F_{j t}$ and $F F_{j t}$ are indexes of investment freedom and financial freedom respectively. Expected coefficients are negative.

\subsection{Data Availability}

Considering the availability of data and the current status of trade between Jiangsu Province and countries along the Belt and Road, 48 representative countries are selected. In 2017, Jiangsu Province exports to these sample countries 
accounted for more than 65 percent of its total exports, which proves selected samples are persuasive and representative. The sample period is from 2002 to 2017 with a total of 768 observations. Trade data are compiled from the Jiangsu Statistical Yearbook and http://www.guoyan.com/; Jiangsu's per capita GDP and population data are from the Jiangsu Statistical Yearbook; Per capita GDP and population of 48 economies are from the World Bank's World Development Indicators database; Trade distances between Jiangsu Province and 48 economies are shipping distances between the capital cities of $i$ to country $j$, which are calculated by the distance calculator on the Time and Date website. The data of Establishment duration of diplomatic relations between two trading parties come from the Ministry of Foreign Affairs of China; the boundary variable is a dummy. It takes the value of 1 if countries share the same boundary and equals 0 otherwise. The number of fixed telephone users and air transport passenger per 100 people in the trading countries come from World Bank; Government efficiency indicators come from the World Bank's WGI database; Investment freedom index, financial freedom index, and government stability index come from the American Traditional Foundation.

\section{Empirical Results and Analysis}

\subsection{Model Setting Test and Analysis}

Before the regression, we apply maximum likelihood estimation $L R=-2\left(I n L_{0}-I n L_{1}\right)$ in order to distinguish the set forms of stochastic frontier gravity model and one-step model based on Stata14.0 software.

The test results of likelihood ratio test (see Table 1) show that trade non-efficiency term does exist and varies with time, time-varying model is appropriate in our study. Accept the null hypothesis that boundary variables should not be introduced, maybe common boundaries do not promote export trade due to the development of transportation. The null hypothesis that the duration of diplomatic relations should not be included is refused. In fact, this variable reflects that close exchanges between trading partners, and diplomatic relationship is conducive to promoting foreign trade. According to test results, it can be known that trade inefficiency exists and all models are set correctly. According to above tests, the final setting form of the model is as follows:

Table 1. Likelihood ratio test results.

\begin{tabular}{ccccccc}
\hline MODEL & Null hypothesis & Constrained model & Unconstrained model & Log likelihood & P $>|\mathbf{z}|$ & Conclusion \\
\hline & $\gamma=\mu=\eta=0$ & -1054.59 & -1048.88 & 11.43 & 0.000 & Refuse \\
Main Model & $\eta=0$ & -554.50 & -443.38 & 222.25 & 0.00 & Refuse \\
& $\beta_{4}=0$ & -561.51 & -561.48 & 0.06 & 0.81 & Accept \\
& $\beta_{5}=0$ & -561.51 & -554.38 & 14.26 & 0.00 & Refuse \\
\multirow{2}{*}{ Sub-model } & Exist no inefficiency & -1054.59 & -919.09 & 271.02 & 0.00 & Refuse \\
& Error Setting & -1052.50 & -919.09 & 266.82 & 0.00 & Refuse \\
\hline
\end{tabular}




$$
\begin{aligned}
\ln E X_{i j t}= & \beta_{0}+\beta_{1} \ln \left(G D P D_{i j t} * G D P F_{i j t}\right)+\beta_{2} \ln \left(P O P D_{i j t} * P O P F_{i j t}\right) \\
& +\beta_{3} \ln D I S_{i j}+\beta_{4} \ln R E L A T I O N_{i j}+v_{i j t}-\left(\partial_{0}+\partial_{1} \ln F I X_{j t}\right. \\
& \left.+\partial_{2} \ln A K_{j t}+\partial_{3} I N F_{j t}+\partial_{4} F F_{j t}+\partial_{5} E F F I_{j t}+\partial_{6} P S_{j t}\right)
\end{aligned}
$$

\subsection{Analysis of Results of Stochastic Frontier Gravity Model}

Based on results of applicability test, this paper uses a time-varying stochastic frontier gravity model to conduct an empirical analysis of current state of foreign trade between Jiangsu Province and 48 sample countries from 2002 to 2017. In order to compare the robustness of results, we also lists the results of mixed regression models, real fixed effect models, real random effect models, and time-invariant models in subsequent.

In time-varying model and time-invariant model, the values of $\gamma$ are 0.843 and 0.923 respectively (see Table 2 ), which are close to 1 , indicating that the gap between the actual bilateral trade flows and potentials is mainly caused by trade inefficiencies. The results of $\eta$ in the time-varying model is significantly positive, indicating that trade efficiency between Jiangsu Province and the countries along the route has continued to increase over time.

\subsection{Analysis of Results of One-Step Model}

\begin{tabular}{|c|c|c|c|c|c|}
\hline & (1) OLS & (2) TRE & (3) $\mathrm{TFE}$ & (4) TVD & (5) $\mathrm{TI}$ \\
\hline Constant & $9.655^{\star * *}(8.271)$ & --- & $\begin{array}{l}12.027^{\star * *} \\
(-10.289)\end{array}$ & $\begin{array}{c}17.995^{\star \star *} \\
(4.48)\end{array}$ & $\begin{array}{c}17.763^{\star * *} \\
(4.327)\end{array}$ \\
\hline $\operatorname{Ln}\left(G P^{*} D^{*} \mathrm{PPF}\right)$ & $\begin{array}{l}0.884^{* * *} \\
(32.847)\end{array}$ & $\begin{array}{c}0.605^{\star * *} \\
(-22.264)\end{array}$ & $\begin{array}{c}0.683^{\star * *} \\
(-44.846)\end{array}$ & $\begin{array}{l}0.997^{\star * *} \\
(15.405)\end{array}$ & $\begin{array}{l}0.715^{\star * *} \\
(28.163)\end{array}$ \\
\hline Ln (POPD*POPF) & $0.935^{\star * *}(33.164)$ & $\begin{array}{l}1.023^{\star * *} \\
(-6.134)\end{array}$ & $\begin{array}{c}0.724^{\star * *} \\
(-22.932)\end{array}$ & $\begin{array}{l}0.824^{\star * *} \\
(12.653)\end{array}$ & $\begin{array}{c}0.407^{\star * *} \\
(3.918)\end{array}$ \\
\hline LnDIS & $-0.753^{\star \star \star}(-8.007)$ & $\begin{array}{l}-0.559^{* *} \\
(-2.050)\end{array}$ & $\begin{array}{c}-0.818^{\star * *} \\
(-8.787)\end{array}$ & $\begin{array}{l}-0.437^{\star *} \\
(-2.111)\end{array}$ & $\begin{array}{c}-0.911^{\star * *} \\
(-3.137)\end{array}$ \\
\hline Lnrelation & $0.490^{\star \star *}(6.972)$ & $\begin{array}{l}0.765^{\star * \star} \\
(-4.43)\end{array}$ & $\begin{array}{l}0.185^{\star \star} \\
(-2.444)\end{array}$ & $\begin{array}{c}1.463^{\star * \star} \\
(6.812)\end{array}$ & $\begin{array}{c}0.786^{* * *} \\
(5.543)\end{array}$ \\
\hline$\eta$ & --- & --- & --- & $\begin{array}{c}0.023^{\star * *} \\
(0.003)\end{array}$ & --- \\
\hline$\lambda$ & --- & $\begin{array}{l}1.656^{* * *} \\
(45.25)\end{array}$ & $\begin{array}{c}1.722^{\star * *} \\
(44.01)\end{array}$ & --- & --- \\
\hline$\sigma_{\mu}$ & 1.090 & $\begin{array}{c}0.368^{\star \star *} \\
(15.21)\end{array}$ & $\begin{array}{c}0.370^{\star * *} \\
(14.30)\end{array}$ & 0.752 & 2.231 \\
\hline$\sigma_{v}$ & 0.705 & $\begin{array}{l}0.222^{\star * \star} \\
(13.41)\end{array}$ & $\begin{array}{c}0.2148^{\star \star *} \\
(12.46)\end{array}$ & 0.140 & 0.186 \\
\hline$\gamma$ & --- & --- & --- & $0.843^{* * *}$ & $0.923^{\star * *}$ \\
\hline Observations & 768 & 768 & 768 & 768 & 768 \\
\hline Log likelihood & -1054.595 & -484.055 & -361.881 & -443.375 & -554.498 \\
\hline
\end{tabular}

In order to further verify the applicability of non-efficiency models, in this section,

Table 2. Empirical results of stochastic frontier gravity model.

Note: The values in parentheses are $t$ statistics; ${ }^{*}{ }^{* *}$, and $^{* * *}$ indicate significant levels at $10 \%, 5 \%$, and $1 \%$, respectively. 
we use likelihood estimation to estimate models with different numbers of variables. The sixth Model includes all explanatory variables in(2), and the remaining 5 models exclude $A K_{j t}, I N F_{j t}, F F_{j t}, P S_{j t}$ and $F I X_{j t}$ in order.

The above regression results (see Table 3 ) indicate that non-efficiency terms are set reasonably and results are robust. From the point of view of natural factors, one-step regression (model 6) indicates that the level of economic development, market size, and duration of diplomatic relations have promoted Jiangsu Province to expand foreign trade to countries along the Belt and Road, while trade distances hinder trade to some extent. Specifically, the coefficient for the level of economic development is significant and positive. The higher the level of per capita GDP of both trading parties, the greater the potential consumption demand of the export market, which is more conducive to the expansion of bilateral trade. The level of economic development between Jiangsu Province and trading partners can drive an increase in trade turnover. The elasticity coefficient of population size is positive, and an increase in the population can bring more trade opportunities. The establishment duration of diplomatic relations is also an important factor accelerating bilateral trade and trade efficiency of Jiangsu Province. The distance is negatively related to exports. To some extent, the farther the distance is, the higher the transportation cost will be.

Secondly, from the perspective of human factors, variable coefficient of airline passenger traffic is positive but not significant, and variable coefficient of fixed telephone subscribers is significantly positive affecting trade efficiency. Both variables representing infrastructure facilitation exert negative influence on export trade of Jiangsu Province, which indicates that infrastructure of the countries along the route has yet to be improved, and poor infrastructure has restricted trade efficiency of Jiangsu Province to a certain extent.

Investment freedom can improve inefficient trade, indicating that the level of investment facilitation can significantly increase trade efficiency between Jiangsu and countries along the route. While an excessively loose financial system may induce financial security issues and disrupts financial markets, so the variable of financial freedom is positively related to trade inefficiency terms. The variable coefficient of government efficiency is significantly negative, confirming that government efficiency can ensure effective implementation of trade policies, reduce administrative barriers, and help improve trade efficiency. Political stability is a main factor influencing Jiangsu Province's trade with partners along the route, and this variable is conducive to foreign trade between trading countries.

\section{Analysis on Trade Efficiency and Potentials of Jiangsu Province with Countries along the Belt and Road}

\subsection{Analysis of Trade Efficiency and Potentials from National Perspective}

Trade efficiency index reflects the extent to which trade potential is realized. Based on regression results above, two sets of trade efficiency values can be 
Table 3. Empirical results of trade inefficiency and its determinants.

\begin{tabular}{|c|c|c|c|c|c|c|c|}
\hline & Independent variable & Model 1 & Model 2 & Model 3 & Model 4 & Model 5 & Model 6 \\
\hline \multirow[t]{5}{*}{$\begin{array}{c}\text { Time-varying SFA } \\
\text { model }\end{array}$} & Constant $\beta_{0}$ & $\begin{array}{l}8.989^{* * *} \\
(-8.924)\end{array}$ & $\begin{array}{l}8.070^{* * *} \\
(-8.166)\end{array}$ & $\begin{array}{l}6.868^{* * *} \\
(-6.699)\end{array}$ & $\begin{array}{l}6.885^{* * *} \\
(-6.649)\end{array}$ & $\begin{array}{l}6.966^{* * *} \\
(-6.632)\end{array}$ & $\begin{array}{l}6.824^{* * *} \\
(-6.294)\end{array}$ \\
\hline & $\operatorname{Ln}\left(\mathrm{GDPD}^{\star} \mathrm{GDPF}\right)$ & $\begin{array}{l}0.769^{* * *} \\
(-32.329)\end{array}$ & $\begin{array}{l}0.769^{* * *} \\
(-32.845)\end{array}$ & $\begin{array}{l}0.771^{\star * \star} \\
(-32.512)\end{array}$ & $\begin{array}{l}0.761^{\star * *} \\
(-32.252)\end{array}$ & $\begin{array}{l}0.767^{\star * *} \\
(-31.691)\end{array}$ & $\begin{array}{l}0.782^{\star * *} \\
(-29.239)\end{array}$ \\
\hline & $\operatorname{Ln}\left(\mathrm{POPD}^{\star} \mathrm{POPF}\right)$ & $\begin{array}{l}0.942^{* * *} \\
(-40.83)\end{array}$ & $\begin{array}{c}0.942^{* * *} \\
(-41.901)\end{array}$ & $\begin{array}{c}0.987^{* * *} \\
(-38.892)\end{array}$ & $\begin{array}{c}0.966^{* * *} \\
(-37.763)\end{array}$ & $\begin{array}{l}0.971^{* * *} \\
(-37.146)\end{array}$ & $\begin{array}{c}0.997^{* * *} \\
(-30.985)\end{array}$ \\
\hline & LnDIS & $\begin{array}{c}-0.829^{* * *} \\
(-9.787)\end{array}$ & $\begin{array}{c}-0.698^{* * *} \\
(-8.213)\end{array}$ & $\begin{array}{c}-0.620^{* * *} \\
(-7.183)\end{array}$ & $\begin{array}{c}-0.598^{* * *} \\
(-6.774)\end{array}$ & $\begin{array}{c}-0.609^{* * *} \\
(-6.756)\end{array}$ & $\begin{array}{c}-0.620^{* * *} \\
(-6.656)\end{array}$ \\
\hline & Lnrelation & $\begin{array}{l}0.441^{* * *} \\
(-7.125)\end{array}$ & $\begin{array}{l}0.367^{* * *} \\
(-5.789)\end{array}$ & $\begin{array}{l}0.315^{* * *} \\
(-4.836)\end{array}$ & $\begin{array}{l}0.327^{* * *} \\
(-4.989)\end{array}$ & $\begin{array}{l}0.331^{* * *} \\
(-4.986)\end{array}$ & $\begin{array}{l}0.331^{* * *} \\
(-4.955)\end{array}$ \\
\hline \multirow[t]{7}{*}{$\begin{array}{l}\text { Trade inefficiency } \\
\text { function }\end{array}$} & Constant $\partial_{0}$ & $\begin{array}{l}-0.611^{\star *} \\
(-2.231)\end{array}$ & $\begin{array}{l}-2.262^{\star * *} \\
(-5.471)\end{array}$ & $\begin{array}{l}-2.705^{\star * *} \\
(-5.679)\end{array}$ & $\begin{array}{l}-6.482^{\star * *} \\
(-5.977)\end{array}$ & $\begin{array}{l}-5.566^{\star * *} \\
(-4.612)\end{array}$ & $\begin{array}{c}-7.847^{\star * *} \\
(-3.909)\end{array}$ \\
\hline & EFFI & $\begin{array}{c}-2.024^{* * *} \\
(-8.028)\end{array}$ & $\begin{array}{c}-2.723^{* * *} \\
(-9.081)\end{array}$ & $\begin{array}{c}-2.378^{* * *} \\
(-8.036)\end{array}$ & $\begin{array}{c}-2.948^{* * *} \\
(-8.416)\end{array}$ & $\begin{array}{c}-2.760^{* * *} \\
(-8.006)\end{array}$ & $\begin{array}{c}-2.905^{* * *} \\
(-8.084)\end{array}$ \\
\hline & LnFIX & & $\begin{array}{l}0.530^{* * *} \\
(-5.341)\end{array}$ & $\begin{array}{l}0.673^{* * *} \\
(-6.197)\end{array}$ & $\begin{array}{l}0.623^{* * *} \\
(-5.319)\end{array}$ & $\begin{array}{l}0.609^{* * *} \\
(-4.912)\end{array}$ & $\begin{array}{l}0.587^{* * *} \\
(-4.739)\end{array}$ \\
\hline & PS & & & $\begin{array}{c}-0.621^{* * *} \\
(-3.937)\end{array}$ & $\begin{array}{c}-0.540^{* * *} \\
(-3.287)\end{array}$ & $\begin{array}{c}-0.527^{* * *} \\
(-3.149)\end{array}$ & $\begin{array}{c}-0.447^{* * *} \\
(-2.628)\end{array}$ \\
\hline & $\mathrm{FF}$ & & & & $\begin{array}{l}1.014^{* * *} \\
(-4.497)\end{array}$ & $\begin{array}{l}1.308^{* * *} \\
(-4.644)\end{array}$ & $\begin{array}{l}1.482^{* * *} \\
(-4.562)\end{array}$ \\
\hline & INF & & & & & $\begin{array}{l}-0.505^{* *} \\
(-2.347)\end{array}$ & $\begin{array}{c}-0.524^{* *} \\
(-2.404)\end{array}$ \\
\hline & LnAK & & & & & & $\begin{array}{c}0.132 \\
(-1.579)\end{array}$ \\
\hline \multirow[t]{2}{*}{ reference } & Observations & 768 & 768 & 768 & 768 & 768 & 768 \\
\hline & Log likelihood & -975.372 & -959.641 & -951.160 & -939.063 & -924.372 & -923.224 \\
\hline
\end{tabular}

Note: The values in parentheses are $t$ statistics; ${ }^{*}{ }^{* *}$, and ${ }^{* * *}$ indicate significant levels at $10 \%, 5 \%$, and $1 \%$, respectively.

obtained. Considering trade efficiency could change with time, we estimate trade efficiency based on model (6), and obtain 768 trade efficiency estimations. Besides, based on these equations, we calculate trade potentials.

The following table gives the 16-year average efficiency indexes, actual trade volume, trade potentials, and potentials for trade improvement between Jiangsu Province and countries along the Belt and Road. The average value of trade efficiency is 0.64 .

Jiangsu has the highest export efficiency to Malaysia (0.94), followed by the Czech Republic (0.92), Cyprus (0.91) and Slovenia (0.90). The export efficiency to Bosnia and Herzegovina is the lowest $(0.10)$, and the gap between the highest value and the lowest value is significant (see Table 4). According to the ranking above, the export efficiency of Jiangsu Province to the top 27 countries is above the average. Among those countries, there are 6 southeast Asian countries, 2 south Asian countries, 9 central and eastern European countries and 10 west Asian countries. The data show Jiangsu Province boasts huge exports and high 
Table 4. Trade potentials and efficiency for improvement of Jiangsu Province exports to trading countries, 2002-2017.

$\$ 10$ thousand

\begin{tabular}{|c|c|c|c|c|c|c|c|}
\hline Countries & $\begin{array}{l}\text { Exports } \\
\text { efficiency }\end{array}$ & $\begin{array}{c}\text { Trade } \\
\text { potentials }\end{array}$ & $\begin{array}{l}\text { Room for trade } \\
\text { potentials }\end{array}$ & Countries & $\begin{array}{l}\text { Exports } \\
\text { efficiency }\end{array}$ & $\begin{array}{c}\text { Trade } \\
\text { potentials }\end{array}$ & $\begin{array}{l}\text { Room for trade } \\
\text { potentials }\end{array}$ \\
\hline Malaysia & 0.94 & $425,285.45$ & $7.28 \%$ & Saudi Arabia & 0.69 & $184,310.73$ & $88.78 \%$ \\
\hline Czech republic & 0.92 & $148,419.51$ & $565.70 \%$ & Kuwait & 0.66 & $32,712.11$ & $946.93 \%$ \\
\hline Cyprus & 0.91 & $20,677.81$ & $569.43 \%$ & Turkey & 0.66 & $304,922.45$ & $259.56 \%$ \\
\hline Slovenia & 0.90 & $20,545.83$ & $136.35 \%$ & Indonesia & 0.63 & $500,540.44$ & $247.82 \%$ \\
\hline Qatar & 0.90 & $17,762.63$ & $774.72 \%$ & Sri Lanka & 0.61 & $46,569.65$ & $257.70 \%$ \\
\hline Estonia & 0.89 & $18,324.68$ & $33.28 \%$ & Mongolia & 0.60 & $10,525.77$ & $517.78 \%$ \\
\hline Hungary & 0.88 & $96,223.61$ & $428.38 \%$ & Bulgaria & 0.59 & $16,685.05$ & $1010.14 \%$ \\
\hline Lithuania & 0.87 & $13,946.01$ & $143.11 \%$ & Ukraine & 0.57 & $100,280.44$ & $-37.84 \%$ \\
\hline Latvia & 0.86 & $14,675.80$ & $73.70 \%$ & Romania & 0.55 & $77,971.16$ & $717.81 \%$ \\
\hline Slovakia & 0.86 & $39,940.21$ & $2106.03 \%$ & Georgia & 0.55 & $7,908.42$ & $42.14 \%$ \\
\hline Israel & 0.84 & $77,117.47$ & $92.14 \%$ & Lebanon & 0.53 & $27,002.59$ & $240.87 \%$ \\
\hline Poland & 0.84 & $201,667.84$ & $723.23 \%$ & Russia & 0.52 & $561,341.61$ & $7.03 \%$ \\
\hline Oman & 0.83 & $17,081.27$ & $931.50 \%$ & Albania & 0.51 & 5183.62 & $843.54 \%$ \\
\hline Singapore & 0.81 & $688,635.56$ & $52.32 \%$ & Myanmar & 0.50 & $94,841.54$ & $106.05 \%$ \\
\hline Thailand & 0.80 & $471,611.73$ & $74.11 \%$ & Egypt & 0.48 & $151,130.62$ & $241.45 \%$ \\
\hline Jordan & 0.80 & $28,144.08$ & $41.49 \%$ & Iran & 0.45 & $251,721.37$ & $157.06 \%$ \\
\hline Croatia & 0.79 & $17,694.14$ & $125.94 \%$ & Pakistan & 0.43 & $230,984.47$ & $194.84 \%$ \\
\hline Vietnam & 0.76 & $440,641.10$ & $69.93 \%$ & Armenia & 0.33 & 3115.83 & $215.76 \%$ \\
\hline Cambodia & 0.76 & $58,304.79$ & $0.91 \%$ & Laos & 0.27 & 9460.03 & $535.31 \%$ \\
\hline The Greek & 0.75 & $77,530.85$ & $589.36 \%$ & Moldova & 0.22 & 3129.48 & $51.20 \%$ \\
\hline Bahrain & 0.74 & 9256.61 & $240.76 \%$ & Belarus & 0.21 & $22,074.69$ & $61.61 \%$ \\
\hline The Philippines & 0.71 & $234,919.61$ & $83.95 \%$ & Azerbaijan & 0.13 & $15,000.56$ & $109.19 \%$ \\
\hline India & 0.70 & $766,335.46$ & $389.48 \%$ & Nepal & 0.11 & $16,483.03$ & $327.81 \%$ \\
\hline Bangladesh & 0.69 & $260,939.02$ & $-21.42 \%$ & $\begin{array}{l}\text { Bosnia and } \\
\text { herzegovina }\end{array}$ & 0.10 & 5914.52 & $88.50 \%$ \\
\hline
\end{tabular}

trade efficiency to Thailand, Malaysia and other Southeast Asian countries, which indicates the importance of Southeast Asian countries for Jiangsu Province. Jiangsu Province exports to Lithuania, Bahrain and other West Asian countries are relatively low with high efficiency, indicating that resistance made by human factors is relatively small, while exports to Iran, Pakistan, and Egypt are higher with lower efficiency, indicating that Jiangsu Province faces greater trade resistance by human factors when exporting to these regions, and the two sides have not achieved the optimal trade outcome. As for trade potentials, there is a large difference between Jiangsu Province and 48 sample countries along the Belt and Road from 2002 to 2017. Specifically, the maximum value of trade potential is 2106.03 percent of Slovakia, and the minimum value is -37.84 percent 
of Ukraine. Countries with negative growth are Bangladesh and Ukraine, and trade potential of Jiangsu Province to other 46 countries shows positive growth.

\subsection{Analysis of Trade Efficiency and Potentials from Regional Perspective}

Considering that trade situations of countries in different regions along the Belt and Road are quite different, we calculate average values of trade efficiency and trade potential index of each region in each year, so as to make further dynamic and regional analysis.

From 2002 to 2016, trade efficiency between Jiangsu Province and countries in different regions along the Belt and Road showed a general trend of increase (see Figure 2), with a slow overall growth rate and fluctuations. From the perspective of specific regions, from 2002 to 2008, trade efficiency of Jiangsu Province with Mongolia and 9 Southeast Asian countries has remained at a high level. From 2008 to 2013, it fluctuated significantly, and increased year by year after 2013. In 2017, this figure reached 0.74 . In contrast, trade efficiency between Jiangsu and the 7 CIS countries is obviously lower, but the growth trend is more obvious. In 2002, trade efficiency between Jiangsu and CIS countries was only 0.18 , but it increased to 0.41 in 2017. During the sample period, trade efficiency between Jiangsu Province and Georgia was the highest, with an average value of 0.55, while trade efficiency with Belarus was the lowest, with an average value of 0.21. The overall level of trade efficiency between Jiangsu Province and Central and Eastern Europe is relatively high and it was up to 0.76 in 2017, increasing by 11.42 percent compared to 2002. On the contrary, trade efficiency between Jiangsu Province and both South Asia and west Asia declined. Trade efficiency value of Jiangsu Province with 13 countries in west Asia dropped from 0.71 in 2002 to 0.67 in 2017, and export efficiency of Jiangsu Province with five countries in South Asia dropped from 0.56 in 2002 to 0.53 in 2017.

Trade potential index can effectively discover trade potentials. The index shows Jiangsu Province's trade to 9 countries in East and Southeast Asia, 13

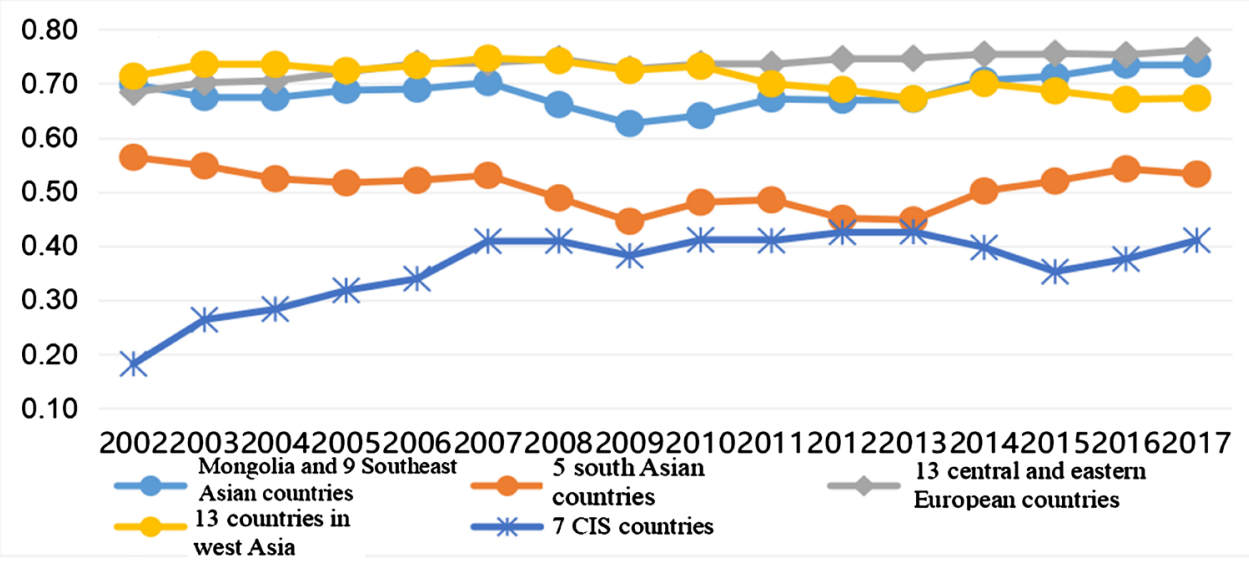

Figure 2. Trend of trade efficiency between Jiangsu Province and countries along the Belt and Road, 2002-2017. 
countries in Central and Eastern Europe, 13 countries in Western Asia, 7 countries in the CIS, and 5 countries in South Asia are all "enormous" (see Table 5), This shows that whether it is a Southeast Asian country with close trade ties with Jiangsu Province, or a CIS country whose trade efficiency needs to be improved, Jiangsu's trade potentials with these countries has not been fully realized.

According to the above analysis, it can be found that inefficient factors of trade have largely restricted foreign efficiency between Jiangsu Province and countries along the Belt and Road, and negative effects of trade barriers cannot be ignored. At the same time, there is still much room to expand trade between Jiangsu Province and countries along the Belt and Road. We can continue to carry out cooperation in various fields and take positive measures to strengthen bilateral trade with countries along the Belt and Road.

\section{Main Conclusions and Countermeasures}

\subsection{Main Conclusions}

First of all, we collect trade data between Jiangsu Province and 48 countries

Table 5. Trade potential indexes of Jiangsu Province and countries along the Belt and Road, 2002-2017.

\begin{tabular}{|c|c|c|c|c|c|}
\hline Year & $\begin{array}{l}\text { Mongolia and } \\
9 \text { Southeast } \\
\text { Asian countries }\end{array}$ & $\begin{array}{l}5 \text { South Asian } \\
\text { countries }\end{array}$ & $\begin{array}{l}9 \text { central and eastern } \\
\text { European countries }\end{array}$ & $\begin{array}{l}13 \text { west Asian } \\
\text { countries }\end{array}$ & $\begin{array}{l}7 \text { CIS } \\
\text { countries }\end{array}$ \\
\hline 2002 & 0.70 & 0.56 & 0.68 & 0.71 & 0.18 \\
\hline 2003 & 0.67 & 0.55 & 0.70 & 0.74 & 0.26 \\
\hline 2004 & 0.67 & 0.52 & 0.71 & 0.74 & 0.28 \\
\hline 2005 & 0.69 & 0.52 & 0.72 & 0.72 & 0.32 \\
\hline 2006 & 0.69 & 0.52 & 0.74 & 0.73 & 0.34 \\
\hline 2007 & 0.70 & 0.53 & 0.74 & 0.75 & 0.41 \\
\hline 2008 & 0.66 & 0.49 & 0.73 & 0.74 & 0.41 \\
\hline 2009 & 0.63 & 0.45 & 0.75 & 0.72 & 0.38 \\
\hline 2010 & 0.64 & 0.48 & 0.74 & 0.73 & 0.41 \\
\hline 2011 & 0.67 & 0.49 & 0.74 & 0.70 & 0.41 \\
\hline 2012 & 0.67 & 0.45 & 0.75 & 0.69 & 0.42 \\
\hline 2013 & 0.67 & 0.45 & 0.75 & 0.67 & 0.43 \\
\hline 2014 & 0.71 & 0.50 & 0.75 & 0.70 & 0.40 \\
\hline 2015 & 0.71 & 0.52 & 0.76 & 0.69 & 0.35 \\
\hline 2016 & 0.73 & 0.54 & 0.75 & 0.67 & 0.38 \\
\hline 2017 & 0.74 & 0.53 & 0.76 & 0.67 & 0.41 \\
\hline Avg. & 0.68 & 0.51 & 0.73 & 0.71 & 0.36 \\
\hline $\begin{array}{c}\text { Type of trade } \\
\text { potentials }\end{array}$ & enormous & enormous & enormous & enormous & enormous \\
\hline
\end{tabular}


along the Belt and Road from 2002 to 2017, and find that overall trade scales among them are expanding day by day and trade relationships are getting closer. Then, we employ stochastic frontier gravity model to estimate trade efficiency and its determinants between Jiangsu Province and countries along the routes. The empirical results show that economic level, population size and duration of diplomatic relations are all conducive to promoting export trade of Jiangsu Province. Political stability and government efficiency of trading partners can improve and stabilize trade efficiency. Variables that reflect the level of communications and transportation infrastructure, namely air traffic volume and the number of landline phone owners, financial freedom increase trade volatility.

The estimated results show that from 2002 to 2017, trade efficiency between Jiangsu Province and countries along the Belt and Road is rising in a fluctuating trend, with an average value of 0.67 , thus there is much room for improvement. Jiangsu Province has the highest export efficiency with Malaysia (0.94), followed by the Czech republic, Cyprus and Slovenia (0.10), and the lowest export efficiency to Bosnia and Herzegovina (0.10), with a significant gap between the highest and lowest values. From regional perspective, Jiangsu Province has closer trade relations with West Asia, East Asia, and Southeast Asia, and it is necessary to further strengthen trade cooperation with the CIS. In general, trade efficiency between Jiangsu Province and 9 countries in East and Southeast Asia, 13 countries in Central and Eastern Europe, 13 countries in Western Asia, 7 countries in the CIS, and 5 countries in South Asia all have great great potential, and there is room for trade potentials.

\subsection{Political Advice}

Jiangsu Province's foreign trade depends on economic development and market size, so relevant government organizations can introduce relevant measures to enhance its export capacity and highlight its advantage. At the same time, the government ought to provide convenient services and support for enterprises and work with them to create a business environment conducive to foreign trade, and help enterprises better and faster "go global".

Factors such as good investment environment and governmental effectiveness can help inhibit trade inefficiency and reduce fluctuations. Jiangsu Province ought to implement tax preferential policies and simplify fiscal and taxation procedures at multiple levels, reduce costs and increase efficiency, increase attractiveness of project construction and investment, and strengthen financial co-operations with countries along the route. At the same time, export companies must also have a sense of crisis and guard against financial risks.

The variables measuring infrastructure are not crucial to trade efficiency based on these regressions, which reflects countries along the route need to further improve their national infrastructure. In order to increase exports to countries along the route, Jiangsu Province can use its role as a major economic province to participate in infrastructure construction projects of the countries 
along the route to facilitate unimpeded trade, with a view to reducing trade costs, enhancing trade efficiency of Jiangsu Province to the countries along the route, and increasing trade potentials.

\section{Conflicts of Interest}

The authors declare no conflicts of interest regarding the publication of this paper.

\section{References}

Battese, G. E., \& Coelli, T. J. (1992). Frontier Production Functions, Technical Efficiency and Panel Data: With Application to Paddy Farmers in India. Journal of Productivity Analysis, 3, 153-169. https://doi.org/10.1007/BF00158774

Chang, X. Y., Wang, X. M., \& Han, Z. X. (2018). Analysis on Potential of Agricultural Trade between China and Countries under the Belt and Road Initiative. World Agriculture, 4, 87-95.

Chen, J. Y., \& Chen, D. B. (2018). Opening Degree of Trade, Economic Freedom and Economic Growth: The Analysis of Based on China and Relevant Countries along "One Belt and Road". Wuhan University Journal (Philosophy and Science Edition), 70, 57.

Chen, J. Y., \& Li, Z. R. (2019). Trade Potential and Its Influencing Factors of the Neighboring Countries of China-Pakistan Economic Corridor. Research on Economics and Management, 40, 15-29.

Deng, F. H., Feng, Q. B., \& Tian, L. (2019). A Study on the Efficiency and Potential of China's Petroleum Import under the Belt and Road Initiative. Journal of Chongqing University (Social Science Edition), 5, 18-29.

Hou, M., \& Deng, L. L. (2017). Study on the Efficiency and Potential of the Trade between China and Central and Eastern European Countries: Based on Stochastic Frontier Model. Shanghai Journal of Economics, 7, 107-118.

Hu, A. G., Ma, W., \& Yan, Y. L. (2014). Connotation, Definition and Passage of "Silk-Road Economic Belt" Strategy. Journal of Xinjiang Normal University (Philosophy and Social Sciences), 2, 7-16.

Huang, W. X., \& Gong, X. S. (2014). Empirical Analysis on Impact of International Logistics Performance of Silk-Road Economic Belt on China's Export of Machinery and Electronic Products. Journal of International Trade, 10, 56-66.

Kong, Q. F., \& Dong, H. W. (2015). Trade Facilitation and Trade Potential of Countries along “One Belt One Road” Route. Journal of International Trade, 12, 158-168.

Li, X. Z., \& Lyu, P. P. (2019). Research on Export Trade Potential and Trade Efficiency of China's Equipment Manufacturing Products-An Empirical Study Based on Belt and Road Countries. Journal of International Trade, 1, 80-92.

Lin, Y. F. (2017). One Belt and One Road and Free Trade Zones: China's New Opening-Up Initiative and Initiatives. Journal of Peking University (Philosophy and Social Sciences), 54, 13-15.

Liu, Y. M., Zhu, Y. Q., \& Lv, Y. Q. (2018). Research on the Efficiency and Potentiality of Sino-Russia Bilateral Trade under "the Belt \& Road Initiative"-Based on the Stochastic Frontier Gravity Model. Reform of Economic System, 212, 80-86.

Pei, C. H., Yu, Y., \& Han, Z. X. (2015). “One Belt and One Road” Construction and the Further Opening-Up of China. International Economics and Trade Research, 10, 4-17. 
Sheng, B., \& Li, F. (2016). An International Political and Economic Analysis of "One Belt and One Road" Initiative. Nankai Journal (Philosophy, Literature and Social Science Edition), 1, 52-64.

Sheng, B., \& Liao, M. Z. (2004). Trade Flow and Export Potential in China: A Gravity Model Analysis. Journal of World Economy, 2, 3-12.

Sun, J. Y., \& Liu, H. Y. (2016). Empirical Research on China's Trade Potential under the Belt and Road Initiative. Contemporary Finance \& Economics, 6, 99-106.

Tan, X. J., \& Zhou, M. R. (2015). Export Potential of 21st-Century Maritime Silk Road and Its Determinants: An Empirical Research Based on Stochastic Frontier Gravity Model. Journal of International Trade, 2, 3-12.

Tang, C. L., Shao, J. L., Li, R. X., \& Wang, S. (2018). Export Potential of China's Goods Trade to Countries along the Belt and Road. Economic Geography, 38, 30-37.

Zhang, J. Z., \& Zeng, Y. (2017). The Export Potential of Electromechanical Products between China and Countries along the Silk Road Economic Belt: An Empirical Study Based on Augmented Gravity Model. International Business, 4, 7-17.

Zhang, Y. Y., \& Yin, M. (2018). The Efficiency and Influencing Factors of China's Export to the "The Belt and Road" Countries. Journal of Capital University of Economics and Business, 5, 39-48. 